\title{
COMPARATIVE IN VITRO ANTIOXIDANT ACTIVITY OF ETHYL ACETATE AND ETHANOL EXTRACTS OF CALLICARPA MACROPHYLLA
}

\author{
GANESH N SHARMA ${ }^{1}$, HARJINDER KAUR ${ }^{1 *}$, BIRENDRA SHRIVASTAVA ${ }^{1}$, SATISH CHANDER ARORA ${ }^{2}$ \\ ${ }^{1}$ Department of Pharmacognosy, School of Pharmaceutical Sciences, Jaipur National University, Jaipur, Rajasthan, India. ${ }^{2}$ Department of \\ Pharmaceutical Sciences, RKSD College of Pharmacy, Kaithal, Haryana, India. Email: ysdverma@gmail.com
}

Received: 05 February 2021, Revised and Accepted: 10 March 2021

\section{ABSTRACT}

Objective: The objective of the study was to evaluate and compare the antioxidant activity of (EA and E) ethyl acetate and ethanol extracts of (CM) Callicarpa macrophylla.

Methods: The physiochemical parameters were assessed according to guidelines given by the world health organization. The total content of phenols and flavonoids was assessed by Folin-Ciocalteu and aluminum chloride methods. In vitro, antioxidant activity was screened by (DPPH) 1,1-diphenyl-2picrylhydrazyl and $\left(\mathrm{H}_{2} \mathrm{O}_{2}\right)$ hydrogen peroxide scavenging and reducing power assay.

Results: The physicochemical parameters fulfilled the standards of WHO guidelines. Total phenol and flavonoid content were more in ethanol extract as compared to ethyl acetate extract of CM. The antioxidant activity of ethanol extract was further high as compared to ethyl acetate extract of Callicarpa macrophylla. The $\mathrm{IC}_{50}$ of Callicarpa macrophylla ethanol extract was less than the ethyl acetate extract. So, more antioxidant activity of ethanol extract compared to ethyl acetate extract of CM.

Conclusion: Overall, both the extracts showed antioxidant activity and can be used further for diseases that can be managed using antioxidants. Ethanol extract possessed significant antioxidant effects than the ethyl acetate extract.

Keywords: Callicarpa macrophylla, Antioxidant activity, Total flavonoid content, Phenol content, Physical evaluation.

(c) 2021 The Authors. Published by Innovare Academic Sciences Pvt Ltd. This is an open access article under the CC BY license (http://creativecommons.org/ licenses/by/4.0/) DOI: http://dx.doi.org/10.22159/ajpcr.2021v14i5.41014. Journal homepage: https://innovareacademics.in/journals/index.php/ajpcr

\section{INTRODUCTION}

Free radicals are those molecules which occupy one or more electron in the outermost orbital. To make themselves stable, they damage other molecules such as DNA, lipids, and proteins. Thus, forming a chain reaction of unstable molecules and resulting in the formation of reactive oxygen species such as superoxide anion, hydrogen peroxide, and hydroperoxyl radicals. Reactive oxygen species spawn consistently in living organisms and (FRS) free radical scavengers are the substances that protect cell damage by interrupting the chain reaction of free radicals [1]. Several plants are used traditionally for the treatment of diseases such as Alzheimer's, wound healing, rheumatism, inflammation, heart disease, and esophageal, prostate, and breast cancer and they showed the presence of polyphenolic compounds which are the richest sources of FRS or antioxidants [2]. Thus, FRS (antioxidant activity) is a significant method of authentication of antioxidants in traditionally used medicinal plants. Callicarpa macrophylla leaves were selected based on their traditional uses in inflammation and as an analgesic and antipyretic [3,4]. CM is found abundantly in India, Asia, Thailand, and Pakistan. In India, it is widely spread in Kashmir, Odessa, Meghalaya, Tripura, and Punjab up to an altitude of $1800 \mathrm{~m}$ [5]. The leaves are used in gout and rheumatic pain [6]. Decoctions of the leaves are used in the treatment of diarrhea, dysentery and to arrest bleeding. The juice made from leaves is used in gastric trouble, headache, and to stop bleeding [7]. Leaves contain calliterpenone, apigenin, docosanoic acid, tricosanoic acid, and tetracosanoic acid. Luteolin, $\beta$-sitosterol- $\beta$-Dglucoside, ursolic acid, fatty acids, and quercetin are also present [8].

\section{METHODS}

Plant materials and chemical reagents

For the current study, the leaves of CM were used. Leaves were purchased from an herbal market in Pune and authenticated by Dr. G.S. Kritikar, Head Pharmacognosist, Samanthak enterprises, Pune (Voucher Specimen Number SE/AC/2019/05). All the chemicals used were of analytical grade. Folin-Ciocalteu reagent, 2, 2-diphenyl-1picrylhydrazyl Gallic acid, and quercetin were procured from SigmaAldrich.

\section{Physiochemical evaluation}

The parameters such as foreign matter, ash value, extractive value, and moisture content were assessed according to the WHO guidelines for the standardization of herbal medicines [9].

\section{Soxhlet extraction}

The plant materials were defatted with petroleum ether and extraction was done with ethyl acetate and ethanol. The extracts obtained were evaporated to make a concentrated mass and the percentage of yield was calculated based on the air-dried weight of the plant material [10].

\section{Chemical tests for analyzing chemical constituents}

The ethyl acetate and ethanol extracts of the leaves of CM (CMEA and $\mathrm{CME}$ ) were analyzed for the plant constituents according to the standard procedures $[10,11]$.

\section{Estimation of total phenolic content}

The total phenol content was determined using the Folin-Ciocalteu method. Briefly, $1 \mathrm{ml}$ of extracts solution was mixed with $2.5 \mathrm{ml}$ of $10 \%(\mathrm{w} / \mathrm{v}$ ) Folin-Ciocalteu reagent. After $5 \mathrm{~min}, 2.0 \mathrm{ml}$ of freshly prepared $\mathrm{Na}_{2} \mathrm{CO}_{3}(7.5 \% \mathrm{w} / \mathrm{v})$ was subsequently added to the mixtures and incubated at room temperature for $10 \mathrm{~min}$ with intermittent agitation. Afterward, the absorbance was measured utilizing a UV Spectrophotometer at $765 \mathrm{~nm}$ against a blank without the extract. The outcome data were expressed as $\mathrm{mg} / \mathrm{g}$ of Gallic acid equivalents in milligrams per gram (mg GAE/g) of the dry extract [12].

Estimation of total flavonoid content

One milliliter of extracts solution was mixed with $0.2 \mathrm{ml}$ of $10 \%$ $(\mathrm{w} / \mathrm{v}) \mathrm{AlCl}_{3}$ solution in methanol, $0.2 \mathrm{ml}(1 \mathrm{M})$ potassium acetate, and 
$5.6 \mathrm{ml}$ distilled water. The mixture was incubated for $30 \mathrm{~min}$ at room temperature followed by the measurement of absorbance at $415 \mathrm{~nm}$ against the blank. The outcome data were expressed as $\mathrm{mg} / \mathrm{g}$ of quercetin equivalents in milligrams per gram $(\mathrm{mg} \mathrm{Qu} / \mathrm{g})$ of the dry extract [13]

\section{Assessment of FRS activity}

This was performed using DPPH, $\mathrm{H}_{2} \mathrm{O}_{2}$, and reducing power assays.

\section{DPPH assay}

The radical scavenging activity of the crude extracts was adapted to measure antioxidant activity using the DPPH assay. Control was prepared by adding $1 \mathrm{ml}$ of methanol in $2 \mathrm{ml}$ of DPPH. The standard used was ascorbic acid at the concentration of $100 \mu \mathrm{g} / \mathrm{ml}$. Briefly, $2 \mathrm{ml}$ of extract solution $(20-100 \mu \mathrm{g} / \mathrm{ml})$ and methanol were added to $2 \mathrm{ml}$ of DPPH $(0.1$ $\mathrm{mM}$ ) solution and control separately. The mixtures were kept aside in a dark area for $30 \mathrm{~min}$ and absorbance was measured at $\lambda$ max $515 \mathrm{~nm}$ against an equal amount of DPPH and methanol as a blank. The percentage of DPPH scavenging was estimated using the equation $[14,15]$

$\%$ scavenging of $\mathrm{DPPH}=[(\mathrm{A} 0-\mathrm{A} 1) \div \mathrm{A} 0] \times 100$

where $\mathrm{A} 0=$ absorbance of the control and $\mathrm{A} 1=$ absorbance of the test extracts

\section{$\mathrm{H}_{2} \mathrm{O}_{2}$ assay}

The FRS activity of individual extracts was determined using the $\mathrm{H}_{2} \mathrm{O}_{2}$ method. Briefly, $2 \mathrm{ml}$ of extract solution $(20-100 \mu \mathrm{g} / \mathrm{ml})$ and methanol were added to $4.0 \mathrm{ml}$ of $\mathrm{H}_{2} \mathrm{O}_{2}(40 \mathrm{mM})$ solution in phosphate buffer (pH 7.4). After $10 \mathrm{~min}$, the absorbance was measured at $\lambda$ max $230 \mathrm{~nm}$ against the phosphate buffer blank solution. Ascorbic acid was used as standard [14]. The same procedure was used for all extracts.

The percentage scavenging of $\mathrm{H}_{2} \mathrm{O}_{2}$ was calculated using the equation:

$\%$ scavenging of $\mathrm{H}_{2} \mathrm{O}_{2}[(\mathrm{~A} 0-\mathrm{A} 1) \div \mathrm{A} 0] \times 100$

where $\mathrm{A} 0=$ absorbance of the control and $\mathrm{A} 1=$ absorbance of the test extracts

\section{Reducing power assay}

The reducing powers of the individual extracts, that reflected their antioxidant activity were determined using the modified $\mathrm{Fe}^{3+}$ to $\mathrm{Fe}^{2+}$ reduction assay. Briefly, $1 \mathrm{ml}$ of extract solution $(10-100 \mu \mathrm{g} / \mathrm{ml})$ and methanol were added to $2.5 \mathrm{ml}$ of $0.2 \mathrm{M}$ sodium phosphate buffer ( $\mathrm{pH}$ 6.6) and $2.5 \mathrm{ml}$ of $1 \%(\mathrm{w} / \mathrm{v})$ potassium ferricyanide $\left[\mathrm{K}_{3} \mathrm{Fe}(\mathrm{CN})_{6}\right]$ solution. The mixture was vortexed and incubated at $50^{\circ} \mathrm{C}$ for $20 \mathrm{~min}$ assisted with a vortex shaker followed by the addition of $2.5 \mathrm{ml} 10 \%(\mathrm{w} / \mathrm{v})$ trichloroacetic acid and centrifuged at $3000 \mathrm{rpm}$. Finally, $2.5 \mathrm{ml}$ of the supernatant was mixed with $2.5 \mathrm{ml}$ deionized water and $0.5 \mathrm{ml}$ of $0.1 \%(\mathrm{w} / \mathrm{v})$ ferric chloride. Perl's Prussian blue color was measured at $\lambda$ max $700 \mathrm{~nm}$ against a blank. Ascorbic acid was used as a positive control [16]. The increased absorbance of the mixture indicates greater reducing power.

\section{RESULTS}

At first, an investigation of the physical constants of the leaves of CM was done to check the quality and the purity. The organoleptic characters of CM leaves were mentioned in Table 1 .

Table 1: Observations of organoleptic characters

\begin{tabular}{lll}
\hline S. No. & Parameters & Callicarpa macrophylla \\
\hline 1. & Color & Green \\
2. & Odor & None \\
3. & Taste & Bitter \\
4. & Shape & Ovate-lanceolate \\
5. & Size & $12 \mathrm{~cm} \times 5.3 \mathrm{~cm}$, \\
6. & Texture & Upper surface- Wrinkled \\
& & Lower Surface- Glabrous \\
\hline
\end{tabular}

Physical evaluation

The physical evaluation was done to check the identity, purity, and quality of the crude drug. The foreign organic matter was estimated to check any type of impurity in the drug; it was detected as $1.5 \% \mathrm{w} / \mathrm{w}$, respectively (Table2). The ash values exposed any type of inorganic constituents such as earthy matter and silica present in the drug, thus helps to disclose the quality of the drug. The total ash value was found to be $7.25 \% \mathrm{w} / \mathrm{w}$, respectively. Acid insoluble ash was $0.47 \% \mathrm{w} / \mathrm{w}$ and water-soluble ash was $0.8 \%$ of CM leaves, respectively (Table 2 ). The extractive value reveals the presence of adulterants due to exhausted or inferior drugs. Alcohol soluble extractive value for CM leaves was $12.2 \% \mathrm{w} / \mathrm{w}$, while water-soluble extractive value was $11.95 \% \mathrm{w} / \mathrm{w}$, respectively (Table 2). Loss on drying method helps in exposing the amount of volatile contents and water present in a drug that was noticed as $5.65 \% \mathrm{w} / \mathrm{w}$ for CM leaves. The percentage yield of CMEA and CME was 8.56 and $7.24 \mathrm{w} / \mathrm{w}$, respectively (Table 2).

\section{Qualitative estimation by chemical tests}

Chemical test for ethyl acetate and ethanol extracts of CM leaves showed the presence of different constituents such as alkaloids, carbohydrates, glycosides, phenolic compounds, triterpenoids, and flavonoids (Table 3).

\section{Quantitative estimation}

Quantitative estimation of phenolic and flavonoid content was done. The phenolic content of the CMEA extracts was $75.2 \mathrm{mg} / \mathrm{g}$, while the flavonoid content was $62.5 \mathrm{mg} / \mathrm{g}$, respectively. The phenol content

Table 2: Estimation of physical constants

\begin{tabular}{lll}
\hline S. No. & Plants name & Callicarpa macrophylla \\
\hline 1. & Foreign organic matter $(\% \mathrm{w} / \mathrm{w})$ & 1.5 \\
2. & Total ash $(\% \mathrm{w} / \mathrm{w})$ & 7.25 \\
3. & Water soluble ash $(\% \mathrm{w} / \mathrm{w})$ & 0.80 \\
4. & Acid insoluble ash $(\% \mathrm{w} / \mathrm{w})$ & 0.47 \\
5. & \% Alcohol soluble extractable & 12.2 \\
& matter $(\% \mathrm{w} / \mathrm{w})$ \\
6. & \%Water soluble extractable & 11.95 \\
& matter $(\% \mathrm{w} / \mathrm{w})$ & \\
7. & Loss on drying $(\% \mathrm{w} / \mathrm{w})$ & 5.65 \\
8. & Percentage yield of CMEA & 7.55 \\
9. & Percentage yield of CMEA & 8.56 \\
\hline
\end{tabular}

Table 3: Chemical tests for analyzing chemical constituents

\begin{tabular}{llll}
\hline S. No. & Chemical tests & $\begin{array}{l}\text { CM ethyl } \\
\text { acetate extract }\end{array}$ & $\begin{array}{l}\text { CM ethanol } \\
\text { extract }\end{array}$ \\
\hline 1. & Alkaloids & + & + \\
2. & Carbohydrates & - & - \\
3. & Proteins & - & - \\
4. & Amino acids & - & - \\
5. & Steroids & + & + \\
6. & Phenolic compounds & + & + \\
7. & Glycosides & + & + \\
8. & Flavonoids & + & + \\
9. & Terpenoids & + & + \\
10. & Tannins & - & + \\
\hline
\end{tabular}

Table 4: Total phenol and flavonoid content of ethyl acetate and ethanol extracts of Callicarpa macrophylla

\begin{tabular}{lll}
\hline S. No. & Methods used & $\begin{array}{l}\text { Callicarpa } \\
\text { macrophylla } \mathbf{~} \mathbf{m g} / \mathbf{g})\end{array}$ \\
\hline 1. & $\begin{array}{l}\text { Total phenol content ethyl acetate } \\
\text { extract }\end{array}$ & 75.2 \\
2 & $\begin{array}{l}\text { Total flavonoid content ethyl acetate } \\
\text { extract }\end{array}$ & 62.5 \\
3. & $\begin{array}{l}\text { Total phenol content ethanol extract } \\
\text { Total flavonoid content ethanol } \\
\text { extract }\end{array}$ & 88.4 \\
& & 76.4 \\
\hline
\end{tabular}


of CME extract was $88.4 \mathrm{mg} / \mathrm{g}$, whereas the flavonoid content was $76.4 \mathrm{mg} / \mathrm{g}$, respectively (Table 4 )

FRS activity (DPPH, $\mathrm{H}_{2} \mathrm{O}_{2}$, and reduced power assay)

By the DPPH method, the $\mathrm{IC}_{50}$ value of ascorbic acid, CMEA and CME extract was found to be was found to be $23.44,72.62$ and $55.64 \mu \mathrm{g} / \mathrm{ml}$ respectively (Table 5).

\section{DPPH assay}

The calibration curve of $\%$ inhibition versus concentration $(\mu \mathrm{g} / \mathrm{ml})$ of standard ascorbic acid, CMEA, and CME extracts was plotted in Figs. $1-3$, respectively.

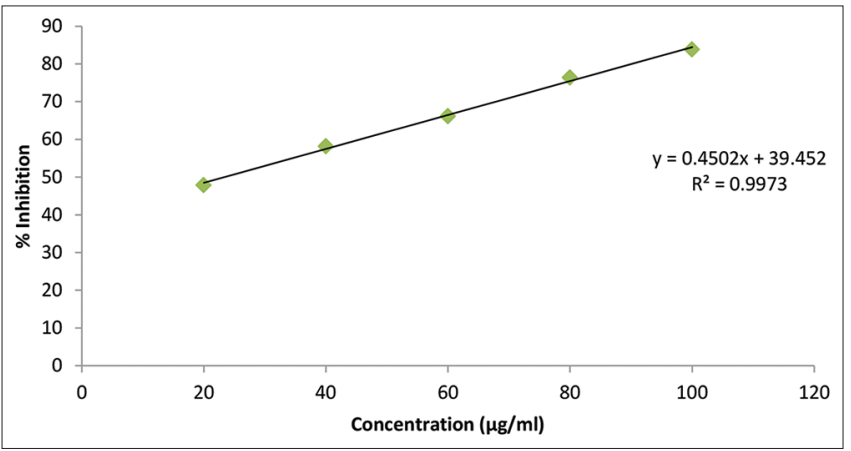

Fig. 1: \% Inhibition of ascorbic acid by DPPH assay

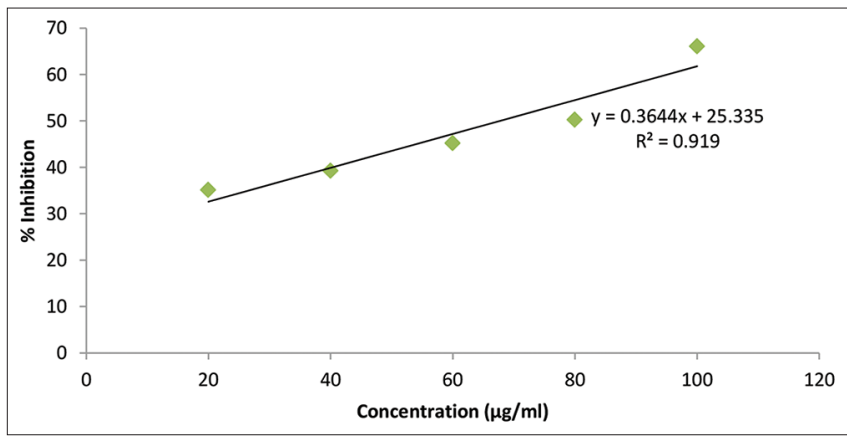

Fig. 2: \% Inhibition of CMEA by DPPH assay

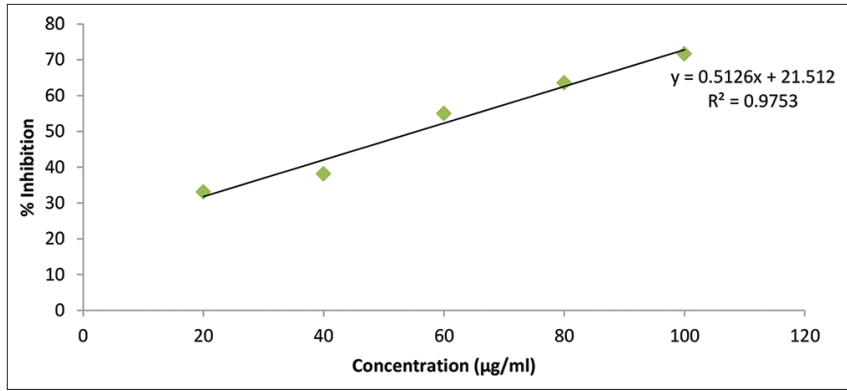

Fig. 3: \% Inhibition of CME by DPPH assay

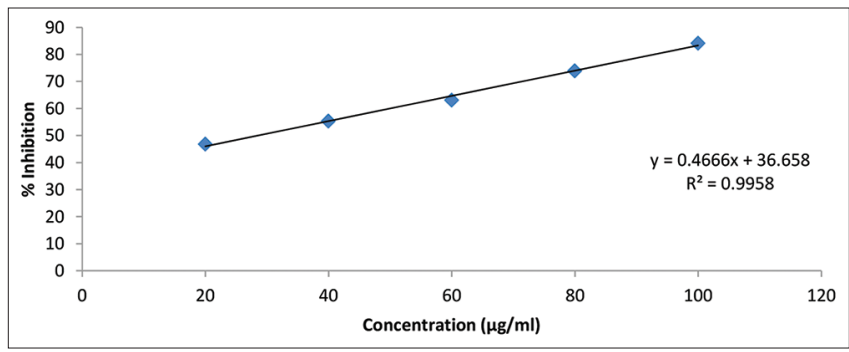

Fig. 4: \% Inhibition of standard ascorbic acid by $\mathrm{H}_{2} \mathrm{O}_{2}$
$\mathrm{H}_{2} \mathrm{O}_{2}$ assay

$\mathrm{By}_{2} \mathrm{O}_{2}$ assay, the $\mathrm{IC}_{50}$ value of ascorbic acid, CMEA and CME extract was found to be was found to be $28.64,81.77$ and $62.79 \mu \mathrm{g} / \mathrm{ml}$ respectively (Table 6).

$\mathrm{By}_{2} \mathrm{O}_{2}$ assay, the calibration curve of $\%$ inhibition versus concentration $(\mu \mathrm{g} / \mathrm{ml})$ of standard ascorbic acid, CMEA, and CME extracts was plotted in Figs. 4-`6, respectively.

\section{Reducing power assay}

The reducing power assay of ethyl acetate extracts showed the absorbance value of $0.182 \%$ and $0.128 \%$ by ascorbic acid and CMEA extracts, while with the ethanol extracts the absorbance was

Table 5: Observations of percentage inhibition of standard ascorbic acid, ethyl acetate, and ethanol extract by DPPH assay

\begin{tabular}{lllll}
\hline S. No. & $\begin{array}{l}\text { Concentration } \\
\text { in } \boldsymbol{\mu g} / \mathbf{m l}\end{array}$ & $\begin{array}{l}\text { \% Inhibition } \\
\text { ascorbic acid }\end{array}$ & $\begin{array}{l}\text { \% } \\
\text { Inhibition } \\
\text { CMEA }\end{array}$ & $\begin{array}{l}\text { \% } \\
\text { Inhibition } \\
\text { CME }\end{array}$ \\
\hline 1. & 20 & $47.86 \pm 0.41$ & $21.74 \pm 0.33$ & $33.08 \pm 0.06$ \\
2. & 40 & $58.15 \pm 0.20$ & $30.52 \pm 0.26$ & $38.12 \pm 0.25$ \\
3. & 60 & $66.15 \pm 0.34$ & $44.01 \pm 0.22$ & $54.98 \pm 0.57$ \\
4. & 80 & $76.34 \pm 0.33$ & $51.48 \pm 0.50$ & $63.53 \pm 0.40$ \\
5. & 100 & $83.78 \pm 0.40$ & $67.06 \pm 0.13$ & $71.63 \pm 0.48$ \\
& & $\mathrm{IC}_{50}=23.44$ & $\mathrm{IC}_{50}=72.62$ & $\mathrm{IC}_{50}=55.64$ \\
\hline
\end{tabular}

All values are Mean \pm SD of three replicate experiments $(n=3)$

Table 6: Observations of percentage inhibition of standard ascorbic acid and ethyl acetate and ethanol extract by $\mathrm{H}_{2} \mathrm{O}_{2}$ assay

\begin{tabular}{lllll}
\hline S. No. Concentration & $\begin{array}{l}\% \\
\text { in } \mu \mathrm{g} / \mathbf{m l}\end{array}$ & $\begin{array}{l}\text { \% Inhibition } \\
\text { ascorbic } \\
\text { acid }\end{array}$ & $\begin{array}{l}\text { Callicarpa } \\
\text { macrophylla }\end{array}$ & $\begin{array}{l}\% \\
\text { Inhibition } \\
\text { Callicarpa } \\
\text { macrophylla }\end{array}$ \\
\hline 1. & 20 & $46.78 \pm 0.12$ & $19.44 \pm 0.40$ & $25.62 \pm 0.51$ \\
2. & 40 & $55.32 \pm 0.33$ & $25.52 \pm 0.49$ & $32.55 \pm 0.48$ \\
3. & 60 & $63.12 \pm 0.14$ & $31.83 \pm 0.24$ & $51.61 \pm 0.44$ \\
4. & 80 & $73.89 \pm 0.15$ & $49.94 \pm 0.34$ & $61.63 \pm 0.32$ \\
5. & 100 & $84.16 \pm 0.16$ & $63.67 \pm 0.13$ & $70.42 \pm 0.13$ \\
& & $\mathrm{IC}_{50}=28.64$ & $\mathrm{IC}_{50}=81.17$ & $\mathrm{IC}_{50}=62.79$ \\
\hline
\end{tabular}

Table 7: Observations of reducing power assay of ethyl acetate extracts of all samples

\begin{tabular}{llll}
\hline S. No. & $\begin{array}{l}\text { Concentration } \\
\text { in } \boldsymbol{\mu} \mathbf{g} / \mathbf{m l}\end{array}$ & Ascorbic acid & CMEA \\
\hline 1. & 10 & $0.077 \pm 0.001$ & $0.041 \pm 0.001$ \\
2. & 20 & $0.101 \pm 0.002$ & $0.048 \pm 0.002$ \\
3. & 40 & $0.119 \pm 0.002$ & $0.075 \pm 0.004$ \\
4. & 60 & $0.139 \pm 0.001$ & $0.100 \pm 0.001$ \\
5. & 80 & $0.150 \pm 0.002$ & $0.119 \pm 0.002$ \\
6. & 100 & $0.182 \pm 0.001$ & $0.128 \pm 0.002$ \\
\hline
\end{tabular}

Table 8: Observations of reducing power assay of ethanol extracts of all samples

\begin{tabular}{llll}
\hline S. No. & $\begin{array}{l}\text { Concentration } \\
\text { in } \boldsymbol{\mu g} / \mathbf{m l}\end{array}$ & Ascorbic acid & CME \\
\hline 1. & 10 & $0.085 \pm 0.001$ & $0.045 \pm 0.001$ \\
2. & 20 & $0.109 \pm 0.001$ & $0.054 \pm 0.002$ \\
3. & 40 & $0.125 \pm 0.001$ & $0.081 \pm 0.002$ \\
4. & 60 & $0.142 \pm 0.001$ & $0.101 \pm 0.002$ \\
5. & 80 & $0.159 \pm 0.002$ & $0.122 \pm 0.002$ \\
6. & 100 & $0.187 \pm 0.002$ & $0.139 \pm 0.002$ \\
\hline
\end{tabular}




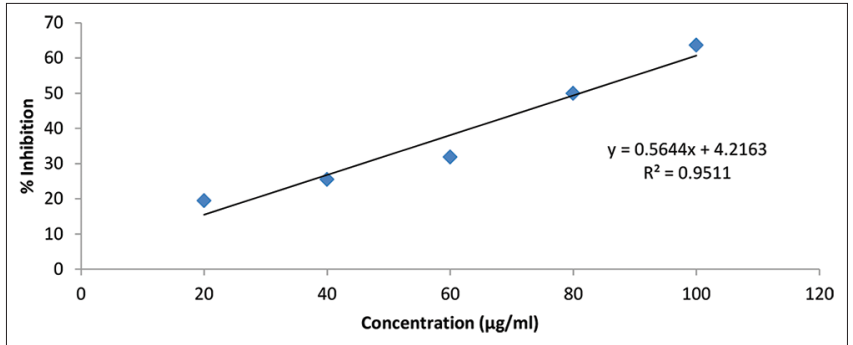

Fig. 5: \% Inhibition of CMEA by $\mathrm{H}_{2} \mathrm{O}_{2}$ assay

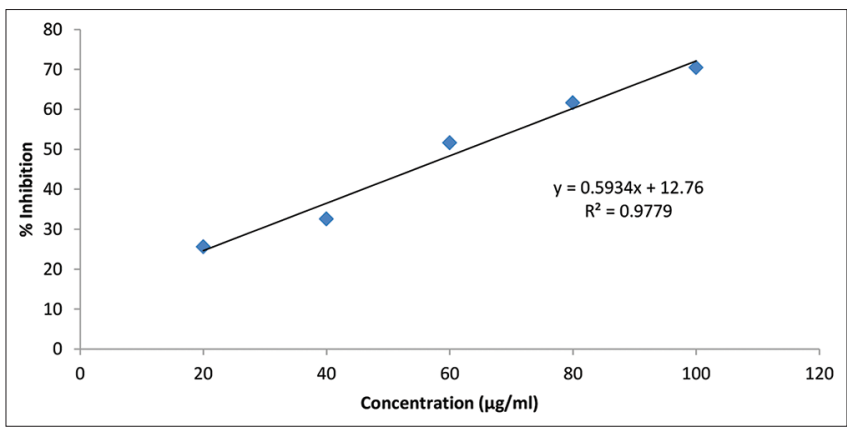

Fig. 6: \% Inhibition of $\mathrm{CME}$ by $\mathrm{H}_{2} \mathrm{O}_{2}$ assay

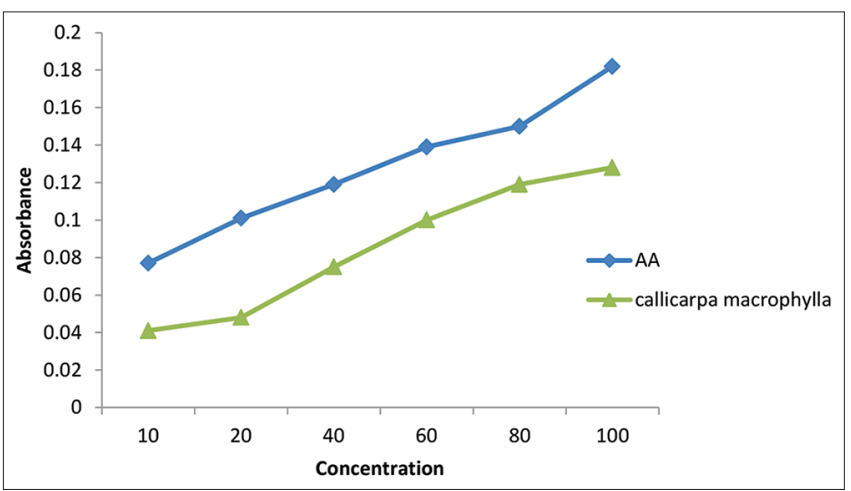

Fig. 7: Reducing power assay of ethyl acetate extracts of all samples

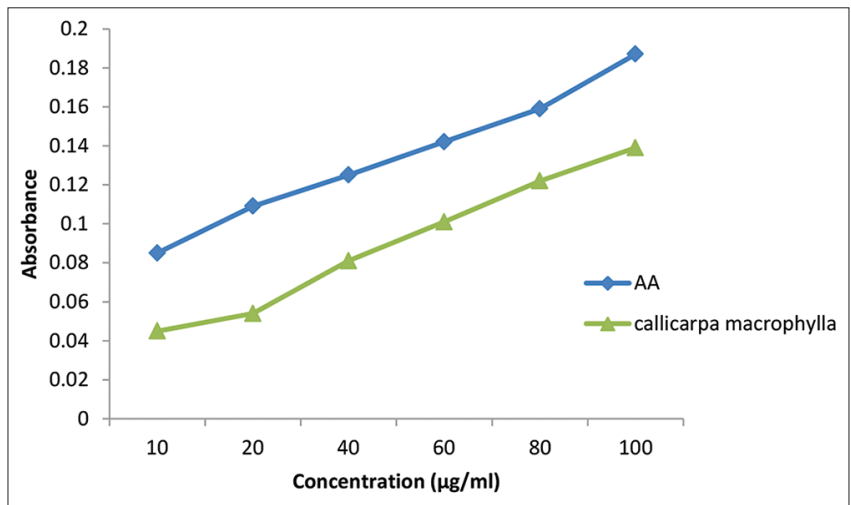

Fig. 8: Reducing power assay of ethanol extracts of all samples

$0.187 \%$ and $0.139 \%$ by ascorbic acid and CME extracts respectively (Tables 7 and 8).

\section{Reducing power assay}

By reducing power assay, the calibration curve of \% inhibition versus concentration $(\mu \mathrm{g} / \mathrm{ml})$ of standard ascorbic acid and CMEA extracts was plotted in Fig. 7, respectively, and for standard ascorbic acid and CME, it was plotted in Fig. 8, respectively.

\section{DISCUSSION}

In our study, a physiochemical evaluation of $\mathrm{CM}$ was done which showed that leaves were of the good quality and purity. Further, polyphenolic compounds were evaluated by qualitative and quantitative evaluation. The phenol and flavonoids contents were present in high amount in ethanol extracts which may be due to different chemical nature of the phenolic compounds in different polarity of the solvents. Further, a significant antioxidant activity was observed by both ethyl acetate and ethanol extracts because of the presence of polyphenols, which are responsible for the depletion of 2,2-diphenyl,1-picrylhydrazyl to 2,2-diphenyl,1-picrylhydrazine to form a blue color complex and conversion of hydrogen peroxide to hydroxyl radicals. The results of reducing power assay further supported the results by showing the good absorbance. As, higher the absorbance of the extracts more will be the antioxidant activity. Previous studies also reported that the phenolic and flavonoid contents are responsible for antioxidant activity [1718]. A study reported in 2016, by Sharma and his coworkers showed that methanol extract of the stem and leaves of Callicarpa arborea has an $\mathrm{IC}_{50}$ value of 53.65 and 47.20 at the concentrations of $100-500 \mu \mathrm{g} /$ $\mathrm{ml}$, respectively containing phenolic compounds [17]. Another study reported that Celastrus paniculatus seeds ethyl acetate extract was $\mathrm{IC}_{50}$ value of 558.58 and $601.81 \mu \mathrm{g} / \mathrm{ml}$ respectively, while the ascorbic acid was $\mathrm{IC}_{50}$ value of 11.24 and $6.83 \mu \mathrm{g} / \mathrm{ml}$ by DPPH and nitric oxide scavenging assay. Many biological activities related to antioxidants are not evaluated yet, so this plant is a better option for those activities [18].

\section{CONCLUSION}

The physicochemical evaluation and antioxidant activity of ethyl acetate and ethanol extracts of CM leave results was in the positive direction, so these plants extracts can be investigated further for the lead compounds and for assessment of different therapeutic activities such as anti-inflammatory, anti-rheumatic, anticancer, and anti-aging which could be due to the antioxidant such as phenol, sterols, and flavonoids and can be used as good replacement therapy to the synthetic drugs.

\section{ACKNOWLEDGMENT}

The authors acknowledge the School of Pharmaceutical Sciences, Jaipur National University, Jaipur and RKSD College of Pharmacy, Kaithal, for providing infrastructure support to conduct the research work.

\section{AUTHORS' CONTRIBUTIONS}

All authors are equally contributed in performing the antioxidant activity and preparation of the manuscript.

\section{CONFLICTS OF INTEREST}

The authors have no conflicts of interest.

FUNDING

Nil.

\section{REFERENCES}

1. Maharaja P, Sengottuvel T, Aarthi A, Gopalasatheeskumar K. Review on antioxidant and hepatoprotective activity of medicinal plants against the paracetamol-induced animal model. Res J Pharmacogn Phytochem 2020;12:114-9.

2. Temple NJ. Antioxidants and disease: More questions than answers. Nutr Res 2000;20:449-59.

3. Yadav V, Jayalakshmi S, Singla RK, Patra A, Khan S. Preliminary assessment of anti-inflammatory activity of Callicarpa macrophylla Vahl. leaves extracts. Indo Glob J Pharm Sci 2011;1:219-22.

4. Yadav V, Jayalakshmi S, Patra A, Singla RK. Investigation of analgesics and antipyretic potentials of Callicarpa macrophylla Vahl. leaves extracts. Int J Med Mol Med 2012;3:1-7. 
5. Sheat WG. Propagation of Trees, Shrubs and Conifers. London: Macmillan and Co. Ltd.; 1948.

6. Sharma P, Yelne M, Dennis T. Database on Medicinal Plants Used in Ayurveda. Vol. 3. New Delhi: Central council for research in Ayurveda and Siddha; 2005.

7. Au DT, Wu J, Jiang Z, Chen H, Lu G, Zhao Z. Ethnobotanical study of medicinal plants used by Hakka in Guangdong, China. $J$ Ethnopharmacol 2008;117:41-50.

8. Verma T, Chandrashekar KS, Joshi AB. $\alpha$-Amyrin caprylate-a new triterpene isolated from the leaf of Bauhinia purpurea Linn. Asian $J$ Res Chem 2009;2:569-70.

9. World Health Organization. Guidelines for the Assessment of Herbal Medicines. Geneva: World Health Organization;1991.

10. Kokate CK, Purohit AP, Gokhale SB. Pathway to screen phytochemical nature of natural drugs. In: Pharmacognosy. $39^{\text {th }}$ ed. India: Nirali Prakashan; 2007. p. 607-11.

11. Raj B, John S, Abdul RA. Pharmacognostic and preliminary phytochemical screening of Ampelocissus indica including antioxidant activity. Res J Pharmacogn Phytochem 2020;12:80-2.

12. Biswas A, Dey S, Li D, Yiu L, Zhang J, Huang S, et al. Comparison of the phytochemical profile, mineral content, and in vitro antioxidant activities of Corchorus capsularis and Corchorus olitorius leaf extracts from different populations. J Food Qual 2020;2020:1-14.

13. Woisky RG, Salatino A. Analysis of propolis: Some parameters and procedures for chemical quality control. J Apicult Res 1998;37:99-105.

14. Bozin B, Mimica-Dukic N, Samojlik I, Goran A, Igic R. Phenolics as antioxidants in garlic (Allium sativum L., Alliaceae). Food Chem 2008;111 Suppl. 4:925-9.

15. Renuka K, Devi VR, Subramanian SP. Phytochemical screening and evaluation of in vitro antioxidant potential of immature palmyra palm (Borassus flabellifer Linn.) fruits. Int J Pharm Pharm Sci 2018;10:77-83.

16. Ruba AA, Mohan VR. In vitro antioxidant potential of the whole plant of Andrographis echioides (1.) Nees (Acanthaceae). Int J Pharm Pharm Sci 2016;8:70-75.

17. Sharma HK, Gogoi B, Nainwal LM. A review on some antioxidant plant species growing in North East India. Int J Pharm Sci Rev 2016;37:224-9.

18. Zohera FT, Habib MR, Imam MZ, Mazumder ME, Rana MS. Comparative antioxidant potential of different extracts of Celastrus paniculatus Willd seed. S J Pharm Sci 2010;1:68-74. 